\title{
Oxidative DNA damage in lung tissue from patients with COPD is clustered in functionally significant sequences
}

This article was published in the following Dove Press journal:

International Journal of COPD

II March 20I I

Number of times this article has been viewed

Viktor M Pastukh'

Li Zhang ${ }^{2}$

Mykhaylo V Ruchko'

Olena Gorodnya'

Gina C Bardwell'

Rubin M Tuder ${ }^{2}$

Mark N Gillespie'

'Department of Pharmacology and Center for Lung Biology, University of South Alabama College of Medicine, Mobile, AL, USA; ${ }^{2}$ Program in Translational Lung Research, Division of Pulmonary Sciences and Critical

Care Medicine, Department of Medicine, University of Colorado at Denver, Aurora, CO, USA
Correspondence: Mark N Gillespie Department of Pharmacology, College of Medicine, University of South Alabama,

Mobile, AL 36688, USA

Tel +I (25I) 460-6497

Fax +I (25I) 460-6798

Email mgillesp@jaguarl.usouthal.edu
Abstract: Lung tissue from COPD patients displays oxidative DNA damage. The present study determined whether oxidative DNA damage was randomly distributed or whether it was localized in specific sequences in either the nuclear or mitochondrial genomes. The DNA damage-specific histone, gamma-H2AX, was detected immunohistochemically in alveolar wall cells in lung tissue from COPD patients but not control subjects. A PCR-based method was used to search for oxidized purine base products in selected 200 bp sequences in promoters and coding regions of the $V E G F, T G F-\beta 1, H O-1, E g r l$, and $\beta$-actin genes while quantitative Southern blot analysis was used to detect oxidative damage to the mitochondrial genome in lung tissue from control subjects and COPD patients. Among the nuclear genes examined, oxidative damage was detected in only 1 sequence in lung tissue from COPD patients: the hypoxic response element (HRE) of the VEGF promoter. The content of VEGF mRNA also was reduced in COPD lung tissue. Mitochondrial DNA content was unaltered in COPD lung tissue, but there was a substantial increase in mitochondrial DNA strand breaks and/or abasic sites. These findings show that oxidative DNA damage in COPD lungs is prominent in the HRE of the VEGF promoter and in the mitochondrial genome and raise the intriguing possibility that genome and sequence-specific oxidative DNA damage could contribute to transcriptional dysregulation and cell fate decisions in COPD.

Keywords: DNA damage, VEGF hypoxic response element, mtDNA, COPD

\section{Introduction}

Multiple lines of evidence show that COPD is inextricably linked to oxidant stress. ${ }^{1-3}$ Sources of oxidants in smoking-related COPD are complex, but probably involve potent oxidants in cigarette smoke as well as oxidants elaborated by infiltrating inflammatory cells and generated as a consequence of cellular signaling. The oxidants so produced appear to target molecules and cellular pathways involved in cell death and lung inflammation. Recent studies have demonstrated in lung and peripheral blood cells from patients with tobacco smoking-related COPD that nucleic acid pools, including guanine incorporated into RNA and DNA, are oxidatively damaged. ${ }^{4-7}$ Accumulation of oxidative damage to nucleic acids by cigarette smoke may lead to an increased risk of cancers and lung aging; 8,9 in fact, COPD lungs have increased expression of markers of cellular senescence, which may correlate with decreased lung repair, further increasing tissue damage that characterizes the progressive and irreversible nature of lung destruction in COPD. ${ }^{10,11}$

Traditional concepts hold that oxidative DNA damage is largely random and it triggers activation of the base excision DNA repair (BER) pathway aimed at the 
removal of the damage to minimize its potentially mutagenic consequences. However, emerging evidence suggests that under some circumstances oxidative DNA damage is not random; damage can be localized to, or more prominent in, either nuclear or mitochondrial (mt) genomes. In this context, while mtDNA appears to be considerably more prone to damage evoked by exogenously applied oxidants than the nuclear genome, ${ }^{12-14}$ specific promoter sequences in particular nuclear genes seem to be targeted for oxidative base damage by stimuli inducing their transcriptional activation. ${ }^{15-19}$

These considerations led us to hypothesize that oxidative DNA damage in lung cells from COPD might be nonrandomly distributed between mitochondrial and nuclear genomes, and in the latter case, could be targeted to specific sequences in specific genes. Because the site of oxidative DNA damage could have important implications for cellular responses underlying COPD pathogenesis, we used complementary strategies to identify lung cell populations harboring DNA damage and then searched for oxidative DNA damage in the mitochondrial and nuclear genomes, including specific sequences of genes linked to development of COPD. Our data indicate that severe COPD is indeed linked to oxidative DNA damage, characterized by prominence to the mitochondrial genome and to a functionally relevant sequence of the VEGF promoter, a gene whose dysregulation has been incriminated in COPD. ${ }^{20-23}$

\section{Methods}

\section{Lung tissue procurement}

Control and lung tissue from patients with GOLD 4 COPD was obtained from the Lung, and Blood Lung Tissue Repository Consortium, provided relevant clinical data. The study was approved by the Johns Hopkins University and University of Colorado Institutional Review Boards. Control lung tissue was histologically normal and derived from patients with no evidence of respiratory dysfunction or COPD.

\section{Immunohistochemical localization of the DNA damage-specific histone, gamma-H2AX}

Paraffin-embedded, formalin-fixed lung tissue specimens were stained immunohistochemically for assessment of the disposition of gamma-H2AX, a DNA damage-specific histone. ${ }^{24}$ We used the mouse monoclonal anti-gammaH2AX (phosphorylated S319) (Abcam, ab 2251, at $1 \mathrm{mg} / \mathrm{mL}$ ) and as negative control, anti-gamma $\mathrm{H} 2 \mathrm{AX}$ incubated with neutralizing peptide (Abcam, ab5649, Cambridge, MA) at 0.1 peptide: 1 antibody molar ratios, as recommended by the manufacturer. Antigen retrieval consisted of incubation with $0.25 \mathrm{mM}$ EDTA at $95^{\circ} \mathrm{C}$, followed by incubation in RT (real time) for 20 minutes. Nonspecific binding sites were blocked with 10\% normal goat serum in Superblock (ScyTek Laboratories, Logan, UT). The detection of antibody binding relied on incubation with a polyclonal goat anti-mouse antibody conjugated to Alexa Fluor 594 (Invitrogen, A11005, $2 \mathrm{mg} / \mathrm{mL}$, Carlsbad, CA) with nuclei stained with 4',6-diamidino-2-phenylindole (DAPI).

Methods for immunohistochemical analyses have been described previously. ${ }^{25}$ Quantification of expression (normalized by total nuclear profiles) was performed in digitally acquired images (10 fields/slide) using MetaMorph ${ }^{\circledR}$ Imaging Software (Molecular Devices, Inc., Sunnyvale, CA).

\section{DNA isolation and DNA damage assessment}

Genomic DNA was isolated from lung tissue specimens using the silica-gel-membrane based DNeasy Tissue Kit (Qiagen, Valencia, CA) with the following modifications implemented to prevent artifactual oxidation: all buffers were purged with nitrogen, and after elution of purified DNA, $1 \mathrm{mM}$ dithiothreitol was added prior to storage at $-80^{\circ} \mathrm{C}$.

A previously reported polymerase chain reaction (PCR)based assay was used to detect base modifications in short sequences of selected nuclear genes. ${ }^{19,26}$ We concentrated our analyses on specific DNA sequences in several genes previously reported to be dysregulated in COPD lung tissue, including the TGF- $\beta 1$, heme oxygenase-1 (HO- $)$, Egrl, and $V E G F$ genes. ${ }^{27-30} \beta$-Actin was used as a "housekeeping" gene. The position of the sequences examined in each gene and primers used to amplify the sequences of interest are listed in Table 1. The basis of the assay is that treatment of DNA with formamidopyrimidine DNA glycosylase (Fpg: New England Biolabs, Beverly, MA) results in strand cleavage at sites of oxidized purines, thereby creating single strand breaks that block PCR amplification. Differences in PCR amplification between Fpg-treated and untreated DNA are thus a specific indicator of the presence of oxidative base damage. The Fpg cleavage reaction was performed by incubating $250 \mathrm{ng}$ of genomic DNA with 8 units of Fpg in 1X NEBuffer $1(10 \mathrm{mM}$ Bis Tris Propane- $\mathrm{HCl}, 10 \mathrm{mM} \mathrm{MgCl}, 1 \mathrm{mM}$ DTT, $\mathrm{pH}$ 7.0) and $100 \mu \mathrm{g} / \mathrm{mL}$ bovine serum albumin in a volume of $50 \mu \mathrm{L}$. Incubations were carried out at $37^{\circ} \mathrm{C}$ for 16 hours. Fpg was then inactivated by heating at $60^{\circ} \mathrm{C}$ for 5 minutes. An aliquot containing $10 \mathrm{ng}$ genomic DNA was then used for the PCR assay to detect Fpg-sensitive cleavage sites. Data are presented as the percentage intact DNA, calculated as the quotient of band intensities in Fpg-treated and untreated DNA $\times 100$. 


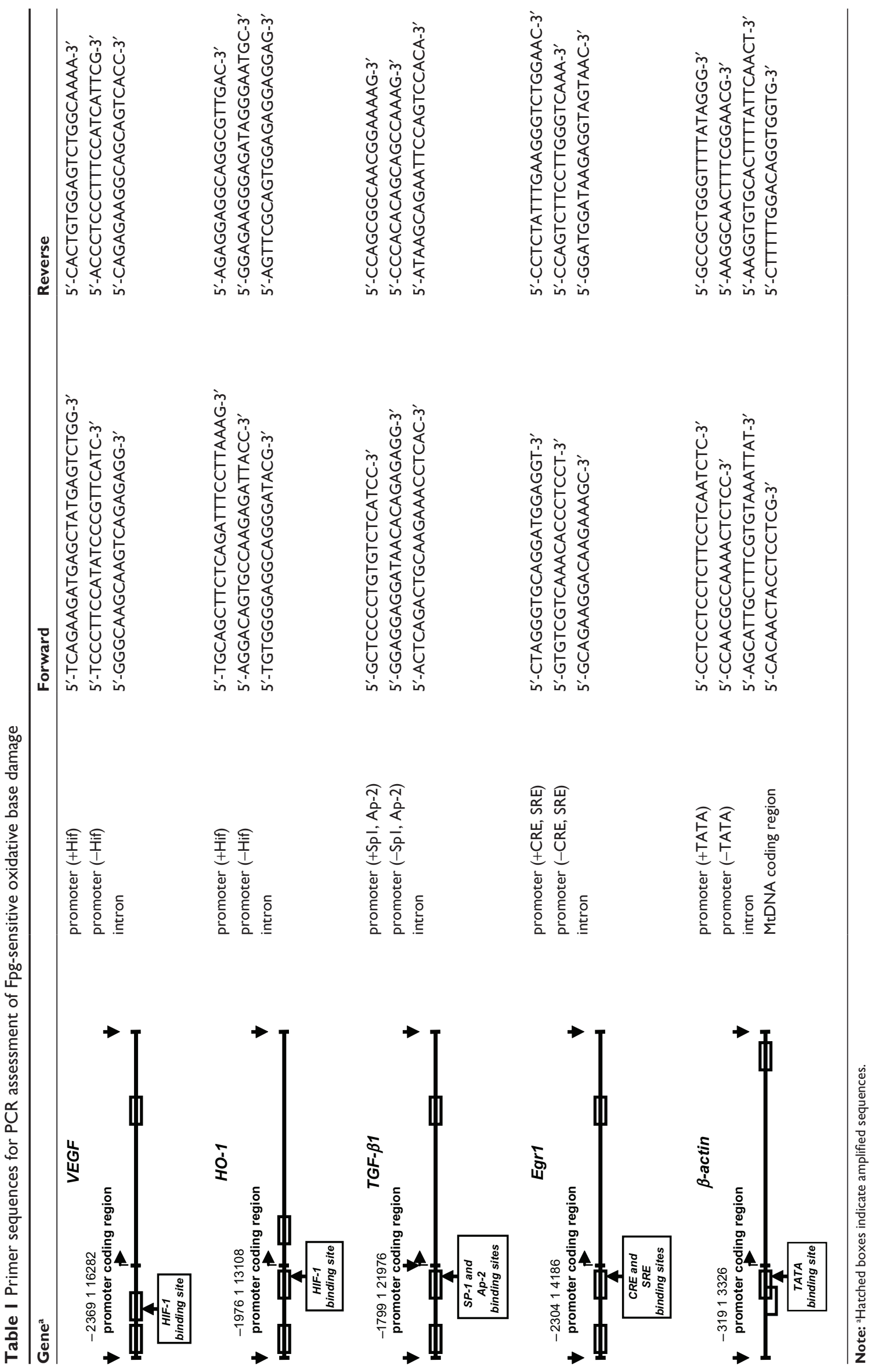


A previously reported quantitative Southern blot technique was used to search for oxidative damage to the mitochondrial genome. ${ }^{13,17}$ After restriction with Bam $\mathrm{H} 1$, samples were resuspended in a small volume of TE buffer and quantified using a Hoefer TKO mini-fluorometer and standards kit. Samples containing 5 to $10 \mu \mathrm{g}$ DNA were heated, cooled at room temperature, and then incubated for 15 minutes with sodium hydroxide $(0.1 \mathrm{~N})$ to cleave DNA at sites of oxidative injury to the deoxyribose backbone. Samples were combined with $5 \mu \mathrm{L}$ loading dye, loaded on to a $0.6 \%$ alkaline gel, and electrophoresed in an alkaline buffer. The DNA was then vacuum-transferred to Hybond $\mathrm{N}+$ membrane (Amersham BioSciences, Little Chalfont, UK) and hybridized with ${ }^{32} \mathrm{P}$-labeled probe overnight at $55^{\circ} \mathrm{C}$. The mtDNA probe was generated using the human mtDNA sequence as the template with PCR primers indicated in Table 1. The 672-bp product hybridized to a $10.5 \mathrm{~kb}$ fragment of human mtDNA obtained after BamHI digestion. This sequence contained the common deletion region incriminated in various "mitochondrial diseases". ${ }^{31}$ The membrane was then exposed to XAR-5 X-ray film (Eastman Kodak Co., Rochester, NY) and images were scanned with a GelLogic 1500 Imaging System (Eastman Kodak Co., Rochester, NY). Changes in the equilibrium lesion density were calculated as - $\ln$ of the quotient of hybridization intensities in treated and control bands.

\section{Slot blot analysis}

Slot blot analysis was used to detect differences in mtDNA content between control and COPD lung tissue. DNA samples were digested with BamHI, precisely quantified, adjusted to the same concentration with $\mathrm{H}_{2} \mathrm{O}$, and treated with $0.3 \mathrm{M} \mathrm{NaOH}$ to denature the DNA. Samples of 100,50 , and $20 \mathrm{ng}$ were blotted onto a nylon membrane (Zeta-probe GT, Bio-Rad, Hercules, CA) using a slot blot apparatus (Hoefer, San Francisco, CA) hybridized with a mtDNA-specific probe, and then washed according to the manufacturer's suggestions.

\section{VEGF mRNA quantification}

VEGF mRNA was determined in control and COPD lung tissue samples using quantitative RT-PCR, as previously described. ${ }^{19}$

\section{Statistical analysis}

Data are presented as either the mean \pm standard error or as scatter diagrams with mean values indicated by a horizontal bar. Group-dependent differences were sought using one-way ANOVAs in conjunction with Neumann-Kuels test when appropriate. Differences were considered significant when $P<0.05$.

\section{Results}

\section{Immunohistochemical detection of histone gamma-H2AX}

We first documented that lungs of advanced COPD patients have expression of the DNA damage-associated histone, gamma-H2AX. While none of the controls had detectable gamma-H2AX immunoreactivity, we noted a wide variation of gamma-H2AX immunoreactivity in GOLD 4 COPD patients with elevated expression ranging from 0.5 to 240 (normalized to the total number of DAPI positive cells). Representative photomicrographs are shown in Figure 1.

\section{Oxidative base damage in nuclear genes}

Table 2 displays the percentage of intact DNA for the indicated promoter and coding sequences in the TGF- $\beta 1$, HO-1, Egrl, and $\beta$-actin genes in normal lung tissue and in lung tissue from patients GOLD 4 COPD. Statistical analyses of these data revealed that oxidative base damage did not differ between groups in any sequence of the
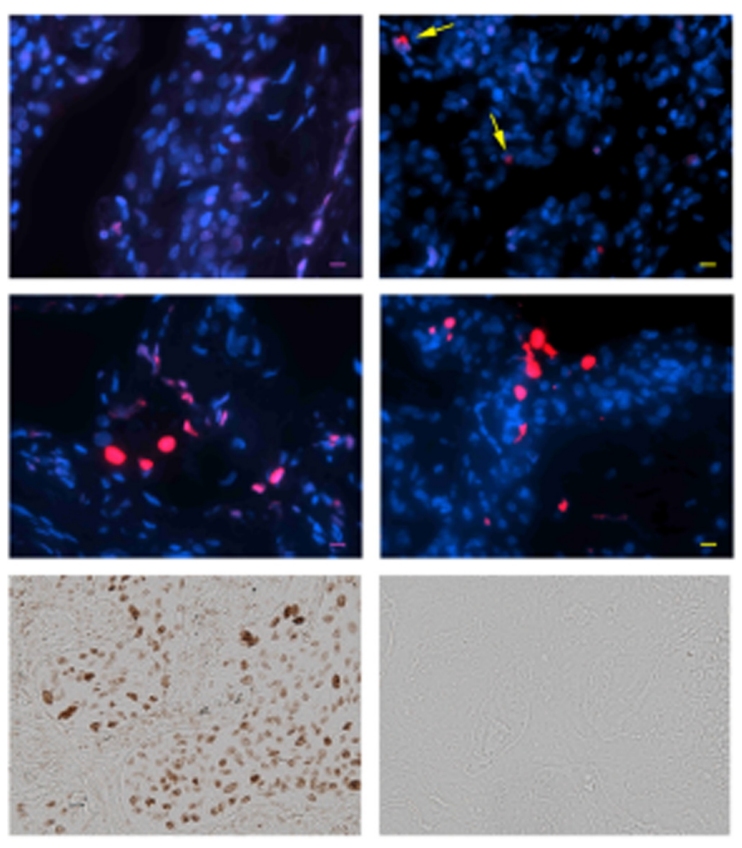

Figure I Expression of gamma-H2AX detected by immunofluorescence or immunohistochemistry (bottom panels) of normal (upper panels) or GOLD 2 (middle left) or GOLD 4 (middle right) representative emphysematous lungs. Note infrequent expression of gamma-H2AX in alveolar septal cells in normal lung (arrows). Positive (bottom left) and negative (peptide absorbed anti-gamma-H2AX antibody; bottom right) control staining of a lung adenocarcinoma detected using immunohistochemistry $($ bar $=10 \mu \mathrm{m})$. 
Table 2 Percentage of intact DNA in specific sequences of COPDrelated genes in control lung and in COPD lung tissue*

\begin{tabular}{llll}
\hline & $\begin{array}{l}\text { Promoter }+ \\
\text { response element }\end{array}$ & $\begin{array}{l}\text { Promoter }- \\
\text { response element }\end{array}$ & $\begin{array}{l}\text { Coding } \\
\text { region }\end{array}$ \\
\hline A. TGF- $\beta$ & & & \\
Control (5) & $99.5 \pm 8.2$ & $92.7 \pm 5.9$ & $85.7+8.2$ \\
COPD (10) & $96.9 \pm 2.0$ & $93.1 \pm 1.6$ & $92.2+4.3$ \\
B. HO-I & & & \\
Control (9) & $98.3 \pm 3.5$ & $96.8 \pm 4.9$ & $98.3 \pm 2.9$ \\
COPD (9) & $81.6 \pm 6.6$ & $87.7 \pm 6.6$ & $85.3 \pm 7.1$ \\
C. EgrI & & & \\
Control (6) & $101 \pm 7.5$ & $86.6 \pm 11.6$ & $85.8 \pm 4.4$ \\
COPD (10) & $77.4 \pm 6.2$ & $82.7 \pm 6.2$ & $92.0 \pm 4.3$ \\
D. $\beta$-actin & & & $85.8 \pm 4.4$ \\
Control (6) & $92.8 \pm 5.9$ & $87.6 \pm 4.2$ & $92.0 \pm 4.3$ \\
COPD (10) & $89.1 \pm 2.0$ & $87.7 \pm 4.2$ & \\
\hline & $\begin{array}{l}\text { Note: } * \text { No significant differences in oxidative base damage were detected between } \\
\text { lung tissues from control subjects and COPD patients for any of the sequences and } \\
\text { genes examined. }\end{array}$
\end{tabular}

indicated genes, though there was a tendency for damage to be present in HRE-containing sequences of the HO- 1 and Egrl promoters. In marked contrast, the scatter diagrams displayed in Figure 2 show that the frequency of oxidative DNA damage in the VEGF promoter sequence containing the HRE was significantly elevated in lung tissue from patients with GOLD 4 COPD in comparison with normal lung tissue. Oxidative base damage frequencies did not differ between the controls and patient groups for a VEGF promoter sequence not containing the HRE or for the coding region of the VEGF gene. Thus, out of 15 sequences examined in 5 different nuclear genes, COPD-related oxidative base damage was prominent in only 1 , the HRE of the VEGF promoter.

Because oxidative damage to the VEGF HRE has the potential to impair VEGF mRNA expression, and since there is some discrepancy in the literature about VEGF mRNA expression in COPD patients, ${ }^{32,33}$ we used quantitative RT-PCR to determine VEGF mRNA abundance in normal lung tissue and lung tissue from patients with GOLD 4 COPD. As shown in Figure 3, we found that the abundance of VEGF mRNA was decreased in COPD lung tissue in comparison with normal lungs.

\section{Mitochondrial DNA content and damage in COPD lung tissue}

Initial experiments showed that there were no differences in mtDNA copy number normalized to nuclear DNA between control lung tissue and lung tissue from patients with GOLD 4 COPD (Figure 4). Because mtDNA copy number does not
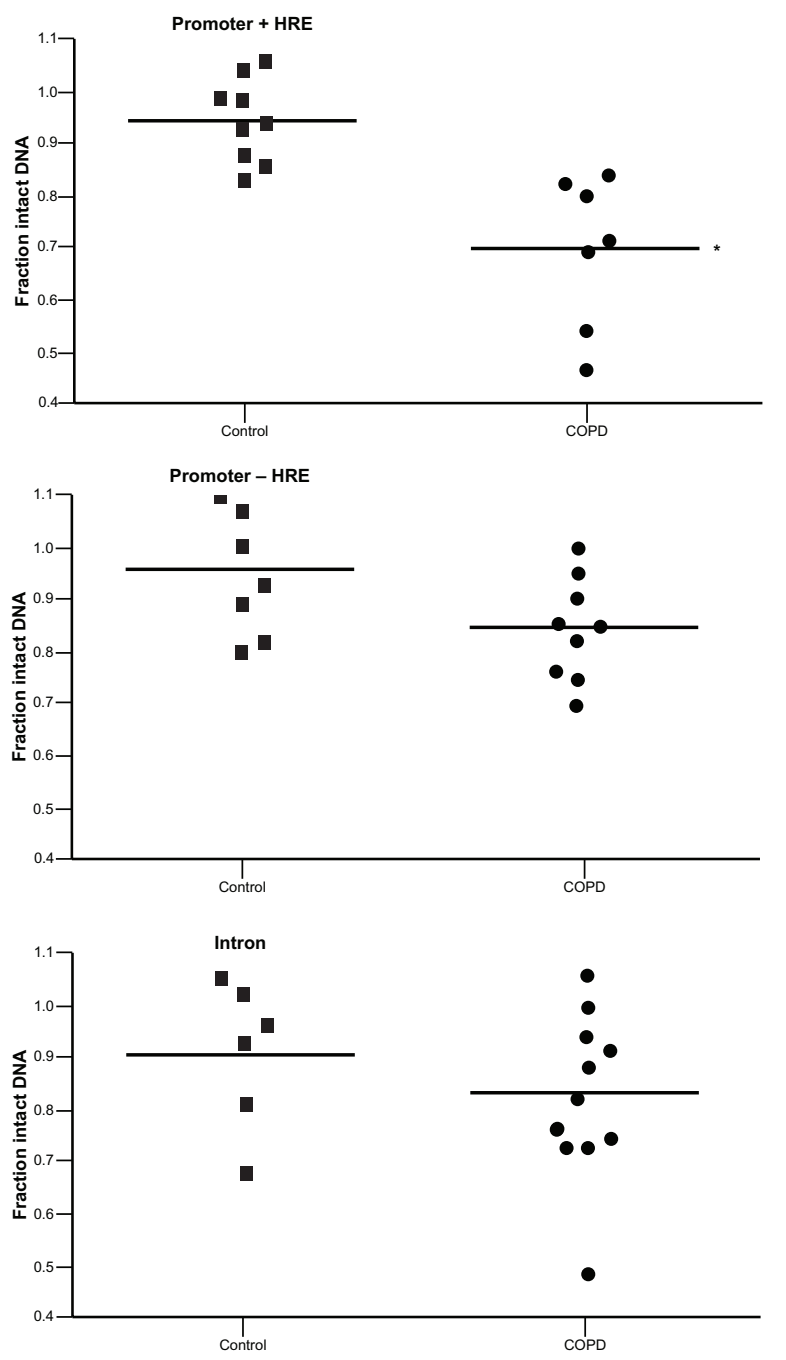

Figure 2 Fpg-sensitive oxidative DNA damage in a VEGF promoter sequence containing the hypoxic response element (HRE; top) but not in a functionally insignificant promoter (middle) or coding (bottom) sequences of the VEGF gene in lung tissue from control subjects and lung tissue from patients with GOLD 4 COPD. See Table I for relative positions of sequences examined. Each point represents lung tissue from an individual patient.

Note: *Significantly decreased "\% intact DNA" in comparison to control at $P<0.05$.

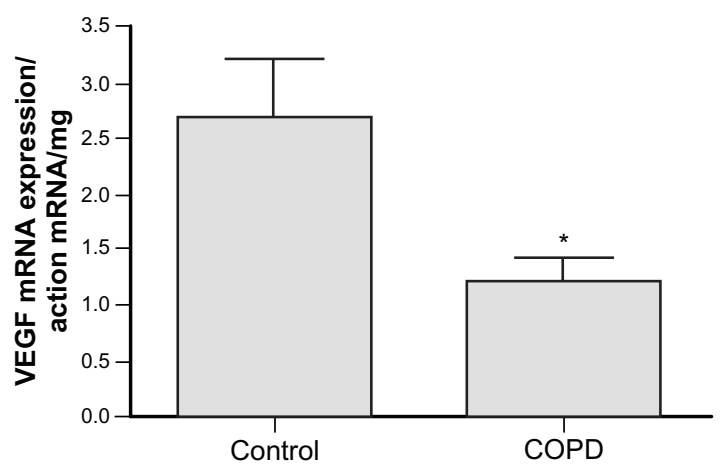

Figure 3 Quantitative RT-PCR analysis of VEGF mRNA abundance in lung tissue from control patients $(n=5)$ and patients with GOLD 4 COPD $(n=10)$.

Note: *Significantly decreased in comparison to control at $P<0.05$. 


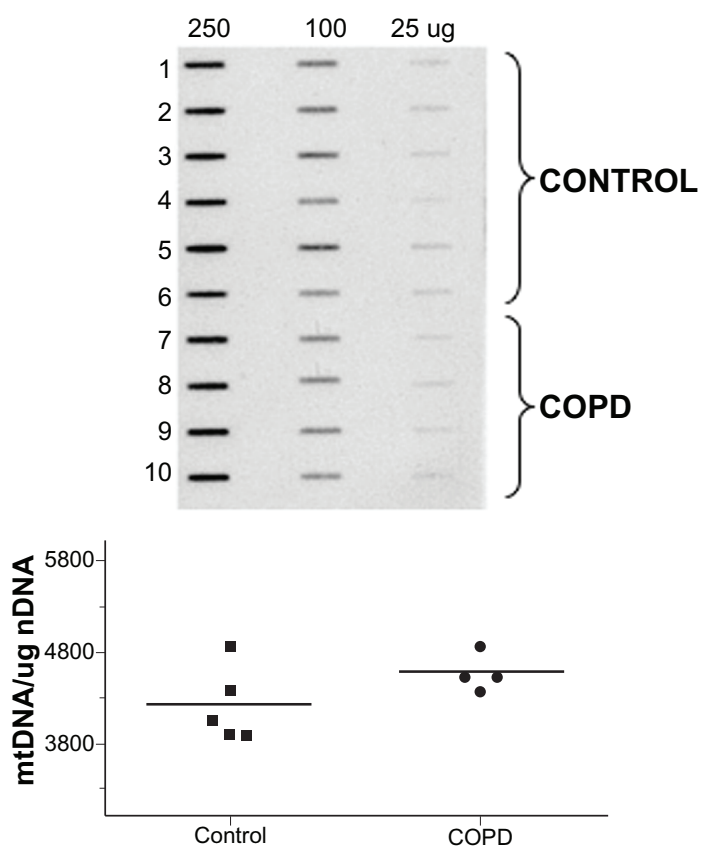

Figure 4 Top: Slot blot for mtDNA in 6 control subjects (rows I-6) and 4 (rows 7-10) patients with GOLD 4 COPD. Note lack of systematic differences in mtDNA hybridization intensities between controls and COPD lung tissue samples at the 3 amounts of total DNA (250-25 $\mu \mathrm{g})$ tested. Bottom: Quantification of mtDNA abundance in control and COPD lung tissues normalized to total DNA. Horizontal bar indicates mean values.

differ between control and COPD lung samples, group-related differences in hybridization intensities for quantitative Southern blot analyses of alkali-treated mtDNA reflect differences in the densities of strand breaks or apurinic/apyrimidinic sites. As shown in Figure 5, lung tissue from patients with
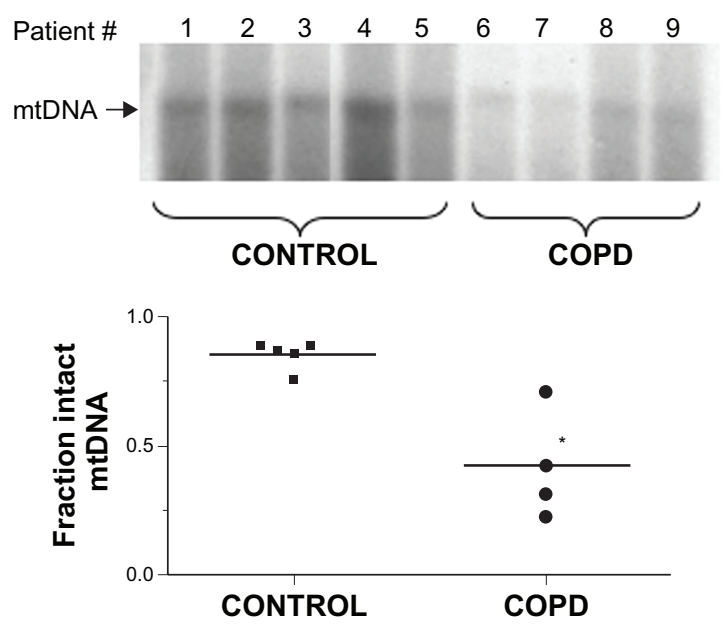

Figure 5 Top: quantitative Southern blot analysis of alkali-labile lesions in a $10.3 \mathrm{~Kb}$ mtDNA sequence obtained from lung tissue from 5 control subjects and from 4 patients with GOLD 4 COPD. Note diminished hybridization intensities in lung tissue samples from patients with COPD. Bottom: quantification of changes in equilibrium lesion densities in a $10.3 \mathrm{~Kb}$ sequence of the mitochondrial genome in control and GOLD 4 COPD lung tissues normalized to total mtDNA abundance. Horizontal bar indicates mean values.

Note: *Significantly decreased "\% intact DNA" in comparison to control at $P<0.05$.
GOLD 4 COPD harbored substantially increased densities of strand breaks and apurinic/apyrimidinic sites in the mitochondrial genome than tissue from normal lungs.

\section{Discussion}

Compelling evidence demonstrates that the oxidant-rich environment associated with tobacco smoking leads to oxidative DNA damage and contributes to the pathogenesis of COPD. ${ }^{1-3}$ Potential sources of DNA-damaging reactive species include oxidants present in cigarette smoke, infiltration of reactive oxygen species (ROS)-generating inflammatory cells and enzymes, and oxidants generated as second messengers in signaling. ROS-dependent DNA damage in COPD has been revealed by immunohistochemical analysis of the common DNA damage product, 8-oxoguanine, and by comet assays that detect strand breaks and base oxidation products. ${ }^{4-7}$ These measurements have been applied to intact lung tissue, isolated lung cells, and circulating nucleated blood cells from smoking and/or COPD patients and to cultured lung cells treated with tobacco smoke extract. In relation to this, the present study shows that the DNA damage-specific histone, gamma-H2AX, is expressed in alveolar septal cells of some of the patients with marked COPD. The evidence of a DNA damage response supports the concept that cigarette smoke can activate cell senescence and/or cell death programs, leading to extensive lung injury and eventual alveolar destruction. . $^{2,34,35}$ Importantly, abnormalities in survival and function of alveolar septal wall cells are known to contribute to COPD pathogenesis. ${ }^{2,8,34,35}$

Traditional concepts hold that oxidative DNA damage is a random event, but emerging data suggest that this may not be so; oxidative DNA damage may, in some circumstances, be more prominent in the mitochondrial genome or in functionally significant sequences of specific nuclear genes. For example, it is known that mtDNA is about 30-fold more sensitive to exogenous oxidants than nuclear DNA. ${ }^{12-14}$ Indeed, in pulmonary and systemic vascular endothelial cells, exogenously applied oxidants cause prominent mtDNA damage at concentrations that fail to affect nuclear DNA integrity, even when highly sensitive oxidative damage detection methods are employed. ${ }^{13,14}$ However, more recent studies suggest that oxygen radicals used as second messengers in physiologic signaling might preferentially target nuclear DNA. In this regard, oxygen radicals generated during hypoxic signaling in pulmonary artery smooth muscle and endothelial cells cause transient oxidative base modifications in promoter sequences, specifically in hypoxic responsive elements in hypoxia-inducible genes. ${ }^{17-19}$ The presence 
of these hypoxia-induced oxidative base modifications in HRE sequences alters transcription factor binding, sequence flexibility, and reporter gene expression. ${ }^{36}$ Similarly, in MCF-7 cells, estrogen causes transient oxidative base damage in estrogen-responsive promoter elements of the $\mathrm{pS} 2$ and Bcl 2 genes. ${ }^{16}$ In this case, the oxidant lesions seem to be caused by hydrogen peroxide generated by the DNA-bound histone demethylase, LSD1, during transcription-related histone demethylation. Finally, studies in cortical neurons from human subjects demonstrate that the age-dependent accumulation of persistent oxidative DNA damage in proximal promoter regions is associated with reduced expression of the affected genes. ${ }^{15}$ Collectively, these findings raise the intriguing possibility that a process of controlled oxidative DNA damage and repair could be linked to modulation of transcriptional activation. ${ }^{16,36}$

Against this background, the aim of the present study was to determine whether the previously reported oxidative DNA damage associated with COPD was randomly distributed between the mitochondrial and nuclear genomes or whether the damage displayed genome and/or sequence specificity. We found that abasic sites and strand breaks could detected in mtDNA from lung tissue from patients with severe COPD, which could reasonably be incriminated in at least several pathologic features of the disease. First, oxidative lesions in the mitochondrial genome have the potential to cause mtDNA mutations and to disrupt mtDNA transcription, ${ }^{31}$ which could contribute to the bioenergetic defects reported in COPD patients. ${ }^{37,38}$ Second, oxidative mtDNA damage is a proximate trigger for apoptosis in a spectrum of cultured cell types, ${ }^{39-42}$ thus suggesting that oxidative damage to the mitochondrial genome in lung cells could initiate apoptotic processes linked to COPD development. ${ }^{43,44}$ Finally, oxidative damage to the mitochondrial genome, probably by increasing mitochondrial oxidant production, also engenders nuclear hypermutability ${ }^{45}$ which may be associated with the increased risk of lung cancer and with acquisition of somatic mutations believed to influence COPD pathogenesis and natural history. ${ }^{46}$

We focused our analysis of nuclear DNA damage on a limited number of genes selected because of their likely pathogenic roles and altered expression in COPD. ${ }^{28-30}$ An interesting finding reported herein was that out of 15 sequences examined in 5 different nuclear genes, Fpg-detectable base lesions were detected exclusively in the VEGF HRE in lungs from COPD patients. The unusual clustering of damage in the VEGF HRE raises intriguing questions about its biological significance, which is discussed below. However, the present observation that the VEGF promoter, among the handful of genes and sequences examined, is oxidatively damaged in COPD points to the need to survey a more extensive list of genes, who may have pathogenic roles and whose expression may be altered, in a larger cohort of COPD patients. In this manner, it might be possible to more clearly define the relation between the presence of promoter damage, alterations in transcript abundance, and other attributes of the pathogenesis and natural history of the disease.

As recently reviewed, VEGF plays a central role in maintaining lung structure and function. ${ }^{20}$ Indeed, in rodent models, when the VEGF receptor type II is blocked pharmacologically or when VEGF signaling is disrupted using genetic strategies, lung cells undergo apoptotic and proliferative responses that culminate in emphysematous-like lesions. ${ }^{21-23}$ In humans with severe COPD, lung VEGF mRNA expression is reduced - a finding confirmed in the present report - and VEGF protein expression is attenuated. ${ }^{33,47-49}$ In light of these considerations, it is tempting to speculate that oxidative damage to the VEGF HRE could suppress VEGF mRNA expression in COPD by altering promoter conformation and impairing transcription factor binding. Countering this idea are recent reports, noted above, suggesting that "controlled DNA damage and repair" in the VEGF HRE and key promoter sequences in other genes could be required for transcriptional activation, possibly by enabling short- and long-range changes in DNA topology. ${ }^{16,36,50}$ The finding that VEGF mRNA expression is decreased in COPD despite the presence of oxidative base modifications postulated to be important for transcriptional activation raises the notion that some aspect of the proposed process of controlled DNA damage and repair can be subverted leading to persistent oxidative damage and an inability to activate gene expression. Obviously, additional experiments will be required to test this concept.

In summary, the present study extends previous reports that oxidative DNA damage is present in lung cells from patients with COPD. The damage appears to be clustered in the mitochondrial genome and in specific sequences of the promoter of the nuclear VEGF gene. The biological importance of this COPD-related, sequence-specific oxidative DNA damage remains to be determined, but it is reasonable to consider the prospect that such oxidative DNA damage could affect cell fate decisions and/or transcriptional regulation of COPD-related genes and thereby contribute to disease pathogenesis.

\section{Acknowledgments}

This work was supported by the Alpha 1 Foundation and the Flight Attendant Medical Research Institute (to RMT), and the 
National Institutes of Health (HL066554 and Project \#1 in PO1 HL085609 to RMT, and HL058234, HL073244, HL084521, and Project \#3 in PO1 HL66299 to MNG).

\section{Disclosure}

The authors declare no conflicts of interest.

\section{References}

1. Drost EM, Skwarski KM, Sauleda J, et al. Oxidative stress and airway inflammation in severe exacerbations of COPD. Thorax. 2005;60(4): 293-300.

2. Yoshida T, Tuder RM. Pathobiology of cigarette smoke-induced chronic obstructive pulmonary disease. Physiol Rev. 2007;87(3):1047-1082.

3. MacNee W. Pathogenesis of chronic obstructive pulmonary disease. Proc Am Thorac Soc. 2005;2(4):258-266; discussion 290-251.

4. Deslee G, Woods JC, Moore C, et al. Oxidative damage to nucleic acids in severe emphysema. Chest. 2009;135(4):965-974.

5. Ceylan E, Kocyigit A, Gencer M, Aksoy N, Selek S. Increased DNA damage in patients with chronic obstructive pulmonary disease who had once smoked or been exposed to biomass. Respir Med. 2006;100(7): 1270-1276.

6. Maluf SW, Mergener M, Dalcanale L, et al. DNA damage in peripheral blood of patients with chronic obstructive pulmonary disease (COPD). Mutat Res. 2007;626(1-2):180-184.

7. Deslee G, Adair-Kirk TL, Betsuyaku T, et al. Cigarette smoke induces nucleic acid oxidation in lung fibroblasts. Am J Respir Cell Mol Biol. 2010;43(5):576-584.

8. Tuder RM. Aging and cigarette smoke: fueling the fire. Am J Respir Crit Care Med. 2006;174(5):490-491.

9. Ito K, Barnes PJ. COPD as a disease of accelerated lung aging. Chest. 2009;135(1):173-180.

10. Yao H, Yang SR, Edirisinghe I, et al. Disruption of $\mathrm{p} 21$ attenuates lung inflammation induced by cigarette smoke, LPS, and fMLP in mice. Am J Respir Cell Mol Biol. 2008;39(1):7-18.

11. Tuder RM, Yun JH, Graham BB. Cigarette smoke triggers code red: $\mathrm{p} 21 \mathrm{CIP} 1 / \mathrm{WAF} 1 / \mathrm{SDI} 1$ switches on danger responses in the lung. Am J Respir Cell Mol Biol. 2008;39(1):1-6.

12. Yakes FM, Van Houten B. Mitochondrial DNA damage is more extensive and persists longer than nuclear DNA damage in human cells following oxidative stress. Proc Natl Acad Sci US A. 1997;94(2):514-519.

13. Grishko V, Solomon M, Wilson GL, LeDoux SP, Gillespie MN. Oxygen radical-induced mitochondrial DNA damage and repair in pulmonary vascular endothelial cell phenotypes. Am J Physiol Lung Cell Mol Physiol. 2001;280(6):L1300-L1308.

14. Ballinger SW, Patterson C, Yan CN, et al. Hydrogen peroxide- and peroxynitrite-induced mitochondrial DNA damage and dysfunction in vascular endothelial and smooth muscle cells. Circ Res. 2000;86(9): 960-966.

15. Lu T, Pan Y, Kao SY, et al. Gene regulation and DNA damage in the ageing human brain. Nature. 2004;429(6994):883-891.

16. Perillo B, Ombra MN, Bertoni A, et al. DNA oxidation as triggered by $\mathrm{H} 3 \mathrm{~K} 9 \mathrm{me} 2$ demethylation drives estrogen-induced gene expression. Science. 2008;319(5860):202-206.

17. Grishko V, Solomon M, Breit JF, et al. Hypoxia promotes oxidative base modifications in the pulmonary artery endothelial cell VEGF gene. FASEB J. 2001;15(7):1267-1269.

18. Ziel KA, Grishko V, Campbell CC, Breit JF, Wilson GL, Gillespie MN. Oxidants in signal transduction: Impact on DNA integrity and gene expression. FASEB J. 2005;19:387-394.

19. Pastukh V, Ruchko M, Gorodnya O, Wilson GL, Gillespie MN. Sequence-specific oxidative base modifications in hypoxia-inducible genes. Free Radic Biol Med. 2007;43(12):1616-1626.

20. Voelkel NF, Vandivier RW, Tuder RM. Vascular endothelial growth factor in the lung. Am J Physiol Lung Cell Mol Physiol. 2006;290(2): L209-L221.
21. Tuder RM, Zhen L, Cho CY, et al. Oxidative stress and apoptosis interact and cause emphysema due to vascular endothelial growth factor receptor blockade. Am J Respir Cell Mol Biol. 2003;29(1):88-97.

22. Taraseviciene-Stewart L, Kasahara Y, Alger L, et al. Inhibition of the VEGF receptor 2 combined with chronic hypoxia causes cell death-dependent pulmonary endothelial cell proliferation and severe pulmonary hypertension. FASEB J. 2001;15(2):427-438.

23. Kasahara Y, Tuder RM, Taraseviciene-Stewart L, et al. Inhibition of VEGF receptors causes lung cell apoptosis and emphysema. J Clin Invest. 2000;106(11):1311-1319.

24. Kuo LJ, Yang LX. Gamma-H2AX - a novel biomarker for DNA doublestrand breaks. In Vivo. 2008;22(3):305-309.

25. Yoshida T, Mett I, Bhunia AK, et al. Rtp801, a suppressor of mTOR signaling, is an essential mediator of cigarette smoke-induced pulmonary injury and emphysema. Nat Med. 2010;16(7):767-773.

26. Ruchko MV, Gorodnya OM, Pastukh VM, et al. Hypoxia-induced oxidative base modifications in the VEGF hypoxia-response element are associated with transcriptionally active nucleosomes. Free Radic Biol Med. 2009;46(3):352-359.

27. Bhattacharya S, Srisuma S, Demeo DL, et al. Microarray data-based prioritization of chronic obstructive pulmonary disease susceptibility genes. Proc Am Thorac Soc. 2006;3(6):472.

28. Ning W, Li CJ, Kaminski N, et al. Comprehensive gene expression profiles reveal pathways related to the pathogenesis of chronic obstructive pulmonary disease. Proc Natl Acad Sci U S A. 2004;101(41): 14895-14900.

29. Stevenson CS, Docx C, Webster R, et al. Comprehensive gene expression profiling of rat lung reveals distinct acute and chronic responses to cigarette smoke inhalation. Am J Physiol Lung Cell Mol Physiol. 2007;293(5):L1183-L1193.

30. Harvey BG, Heguy A, Leopold PL, Carolan BJ, Ferris B, Crystal RG. Modification of gene expression of the small airway epithelium in response to cigarette smoking. J Mol Med. 2007;85(1):39-53.

31. Wallace DC. Mitochondrial diseases in man and mouse. Science. 1999;283(5407):1482-1488.

32. Santos S, Peinado VI, Ramirez J, et al. Enhanced expression of vascular endothelial growth factor in pulmonary arteries of smokers and patients with moderate chronic obstructive pulmonary disease. Am J Respir Crit Care Med. 2003;167(9):1250-1256.

33. Suzuki M, Betsuyaku T, Nagai K, et al. Decreased airway expression of vascular endothelial growth factor in cigarette smoke-induced emphysema in mice and COPD patients. Inhal Toxicol. 2008;20(3): 349-359.

34. Tuder RM, Yoshida T, Arap W, Pasqualini R, Petrache I. State of the art. Cellular and molecular mechanisms of alveolar destruction in emphysema: an evolutionary perspective. Proc Am Thorac Soc. 2006; 3(6):503-510.

35. Tuder RM, Yoshida T, Fijalkowka I, Biswal S, Petrache I. Role of lung maintenance program in the heterogeneity of lung destruction in emphysema. Proc Am Thorac Soc. 2006;3(8):673-679.

36. Gillespie MN, Wilson GL. Bending and breaking the code: dynamic changes in promoter integrity may underlie a new mechanism regulating gene expression. Am J Physiol Lung Cell Mol Physiol. 2007;292(1): L1-L3.

37. Puente-Maestu L, Perez-Parra J, Godoy R, et al. Abnormal mitochondrial function in locomotor and respiratory muscles of COPD patients. Eur Respir J. 2009;33(5):1045-1052.

38. Rabinovich RA, Bastos R, Ardite E, et al. Mitochondrial dysfunction in COPD patients with low body mass index. Eur Respir J. 2007;29(4): 643-650.

39. Dobson AW, Grishko V, LeDoux SP, Kelley MR, Wilson GL, Gillespie MN. Enhanced mtDNA repair capacity protects pulmonary artery endothelial cells from oxidant-mediated death. Am J Physiol Lung Cell Mol Physiol. 2002;283(1):L205-L210.

40. Rachek LI, Grishko VI, Musiyenko SI, Kelley MR, LeDoux SP, Wilson GL. Conditional targeting of the DNA repair enzyme hOGG1 into mitochondria. J Biol Chem. 2002;277(47):44932-44937. 
41. Ruchko M, Gorodnya O, LeDoux SP, Alexeyev MF, Al-Mehdi AB, Gillespie MN. Mitochondrial DNA damage triggers mitochondrial dysfunction and apoptosis in oxidant-challenged lung endothelial cells. Am J Physiol Lung Cell Mol Physiol. 2005;288(3):L530-L535.

42. Harrison JF, Rinne ML, Kelley MR, Druzhyna NM, Wilson GL, Ledoux SP. Altering DNA base excision repair: use of nuclear and mitochondrial-targeted N-methylpurine DNA glycosylase to sensitize astroglia to chemotherapeutic agents. Glia. 2007;55(14):1416-1425.

43. Demedts IK, Demoor T, Bracke KR, Joos GF, Brusselle GG. Role of apoptosis in the pathogenesis of COPD and pulmonary emphysema. Respir Res. 2006;7:53.

44. Plataki M, Tzortzaki E, Rytila P, Demosthenes M, Koutsopoulos A, Siafakas NM. Apoptotic mechanisms in the pathogenesis of COPD. Int J Chron Obstruct Pulmon Dis. 2006;1(2):161-171.

45. Hartman P, Ponder R, Lo HH, Ishii N. Mitochondrial oxidative stress can lead to nuclear hypermutability. Mech Ageing Dev. 2004;125(6): $417-420$.
46. Makris D, Tzanakis N, Damianaki A, et al. Microsatellite DNA instability and COPD exacerbations. Eur Respir J. 2008;32(3):612-618.

47. Kanazawa $H$. Role of vascular endothelial growth factor in the pathogenesis of chronic obstructive pulmonary disease. Med Sci Monit. 2007; 13(11):RA189-RA195.

48. Marwick JA, Stevenson CS, Giddings J, et al. Cigarette smoke disrupts VEGF165-VEGFR-2 receptor signaling complex in rat lungs and patients with COPD: morphological impact of VEGFR-2 inhibition. Am J Physiol Lung Cell Mol Physiol. 2006;290(5):L897-L908.

49. Kanazawa H, Hirata K, Yoshikawa J. Imbalance between vascular endothelial growth factor and endostatin in emphysema. Eur Respir J. 2003;22(4):609-612.

50. Breit JF, Ault-Ziel K, Al-Mehdi AB, Gillespie MN. Nuclear proteininduced bending and flexing of the hypoxic response element of the rat vascular endothelial growth factor promoter. FASEB J. 2008;22(1): $19-29$.

\section{Publish your work in this journal}

The International Journal of COPD is an international, peer-reviewed journal of therapeutics and pharmacology focusing on concise rapid reporting of clinical studies and reviews in COPD. Special focus is given to the pathophysiological processes underlying the disease, intervention programs, patient focused education, and self management protocols.

\section{Dovepress}

This journal is indexed on PubMed Central, MedLine and CAS. The manuscript management system is completely online and includes a very quick and fair peer-review system, which is all easy to use. Visit http://www.dovepress.com/testimonials.php to read real quotes from published authors.

Submit your manuscript here: http://www.dovepress.com/international-journal-of-copd-journal 